\title{
The Effect of Signification, Resource Domination, and Legitimacy and Inclusive Education Legitimacy on Inclusivity of Elementary School in Surakarta City
}

\author{
Ravik Karsidi $^{\mathrm{a}}$, Drajat Tri Kartono ${ }^{\mathrm{b}}$, AnggoroWulansaric * \\ ${ }^{a}$ Faculty of Education, Sebelas Maret University, Indonesia, \\ ${ }^{b}$ Faculty of Social and Political Science, Sebelas Maret University, Indonesia, \\ ${ }^{c}$ Faculty of Social and Political Science, Sebelas Maret University, Indonesia \\ *Corresponding author: angsa3112@gmail.com \\ Article history \\ Received: 10/10/2016 \\ Received in revised form: 14/01/2017 \\ Accepted: 04/03/2017
}

\begin{abstract}
Inclusive education is still new and faces many problems in education service in Indonesia. This research aimed to find out the effect of signification, resource domination, and legitimacy on inclusivity of education and to find out the forms of signification, resourcedomination, and legitimacy in inclusive education in fiteen Elementary Schools organizing inclusive education in Surakarta This research employed a combined quantitative and qualitative method with embedded concurrent strategy. Data collection was carried out using questionnaire, interview, and observation. The subject of research was teacher with confidence level of $95 \%$, and quantitative sample consisted of 246 respondents. The informant for qualitative data consisted of 17 persons taken purposively, using maximum variation sampling technique. The analysis of data was conducted using simple and multiple linear regressions equipped with description of qualitative data using Anthony Giddens' structuring theory. The result of research show that education inclusivity belonged to low category. The result of linear regression calculation showed that the relationship between signification and education inclusiveness was fairly strong and positive (59.2\%). The relationship between resource domination and education inclusiveness was fairly strong and positive $(77.3 \%)$. The relationship between legitimacy and education inclusiveness was fairly strong and positive (66.6\%). The result of multiple regression showed that the relationship between signification, resource domination and legitimacy was simultaneously strong and positive (81\%). The forms of signification, domination and legitimacy of incusive education were includeimmaterials, such as work culture and religious belief values affecting the diversity of education inclusivity.Considering the analysis conducted show that the implementation of inclusive education is still far from its ideal indicators. Many requirements should be met to organize the inclusive education to make this city fasible to be called inclusice city.
\end{abstract}

Keywords: Signification, resource domination, legitimacy, inclusivity, structure, structuring 


\subsection{INTRODUCTION}

School is one of social institutions within which there is a process of socializing norms and values taught to children. Seeing the school, we can see not only its physical forms such as building and infrastructures existing, but also non-physical ones such as social structures including teachers' position, student-teacher relation, relation between teachers and relation between students, social norms and order, school culture, institution and social problems occurring within it.

Karsidi (2008) stated that school education has two important aspects: individual and social. On the one hand, school education serves to affect and to create a condition enabling the students' personal development optimally. On the other hand, school education serves to educate the students to dedicate themselves to the society. An ideal education system will integrate the students into reality, rather than isolate them from diverse society. One of education forms managing that diversity is called inclusive education.

Karsidi (2015) in his split into philosophical standpoint and a technical standpoint about inclusive education. Philosophically, that the right to quality education for every child is important, include the children with special needs. A point of view that the children with special needs should get the same service and quality commensurate with other learners. Further explained that inclusive education is a way of looking how that child with special needs can get a quality education, which is not distinguished for their rights by other learners. But from the standpoint of technical education, inclusive education practices would be in trouble if the infrastructure and human resources are not prepared in earnest. In the technical level is usually debatable and tends to lead to disagreement considering the field conditions are "deemed" not ready.

As described on inclusive education above, it can be said that inclusive education is a way of how to build a system of educational environment (school) which enables all learners with the diverse condition to underserved needs in order to grow and develop optimally both physically, mental, intellectual, emotional and social. Therefore, the inclusion is not just a program or a project but rather a system, that system in creating an effective school environment for a successful education for all children

In line with the above opinion, Puslitjaknov (2008) states that inclusive education is different from the concept of integrated education that focuses on the access given at the regular school children with abnormalities. Inclusive education emphasizes the need for all children to be educated in accordance with the potential and needs. Understanding all the children in this case, including those that have been neglected due to factors such as people with the disorder, living in remote areas, come from poor families, street children or child labor. Because of the scope of inclusive education became widespread because it not only involves the placement of children with abnormalities in regular schools, but also deals with the education system such broader policy in terms of curriculum, testing, management, facilities, educators and reception new students (Yusuf, 2014c).

Kugelmas (2004) mentioned that in the countries that have applied inclusive education for a long time, inclusive education is defined more broadly in the context of school culture emphasizing on how school, class, and curriculum structure are designed for all students in order to attend the learning and to develop optimally (Yusuf, 2014). The implementation of inclusive education in many countries generally refers to international document of Salamanca statement and Framework of Special Need Education Action in 1994.

In line with the world's commitment to inclusive education as mentioned earlier, Indonesian government pays serious attention to and supports the inclusive education through the enactment of Republic of Indonesia's Law Number 20 of 2003 about National Education System. The follow-up of such the law by the Republic of Indonesia's National Education Ministry is carried out by releasing 
the National Education Minister of Republic of Indonesia's Regulation Number 70 of 2009 about Inclusive Education.

There are some fundamental problems in the implementation of inclusive education in Indonesia. Yusuf (2014d) wrote that in the implementation of inclusive education in Indonesia, the following problems could be identified:

1. The problem related to definition, understanding, discourse, and interpretation on inclusive education creating and building symbol, attitude, value, behavior, emotion, and empathy to inclusion.

2. The problem related to adequate resource support, pertaining to the availability of teacher, learning infrastructure, budget to support inclusive program and activity, and even positive partnership network between related stakeholders (government, headmaster, teacher, students, parents, society).

3. The problem related to inclusive education process, pertaining to school institution, curriculum adjustment, learning adjustment (method and media), assessment and evaluation adjustment.

4. The problem related to the function of inclusive education management, pertaining to planning, governance and organization, implementation, monitoring and controlling.

5. The problem related to policy and regulation, including the school's ability of reproducing rule as the form of support and expectation all at once in implementing the inclusive education more optimally based on the school condition.

From the identification of some problems in the implementation of inclusive education in Indonesia, this research limited the discussion to:

1. Problem related to definition, understanding, discourse, and interpretation on inclusive education creating and building symbol, attitude, value, behavior, emotion, and empathy to inclusion (signification)

2. Problem related to the school's resource support to support the implementation of inclusive education (domination)

3. Problem related to policy and regulation, limited to the school's ability of producing and reproducing policy and rule as the form of support and expectation all at once in implementing the inclusive education in the school (legitimacy).

\subsection{FRAMEWORK}

This research focused on an information flow process in inclusive school surfacing in education environment (school) and accepted by the components of education systems so that the interpretations are repeated until the inclusive school is brought into reality. For that reason, the author employed structuring theory suggested by Giddens (1984) as the analytical knife used to study the phenomenon of inclusive school. Varying perceptions on inclusive education among teachers, students and society, attitude and perception on children with special need, socialization of inclusive education not reaching the bottom lead to the poor understanding on inclusive education; the experience with children with special need resulting in differently demonstrated inclusive behavior is the phenomenon of signification concerning inclusive education.

Less optimum mastery and or resource management of school (whether personnel, budget, or infrastructure facility) in implementing the inclusion is the phenomenon of domination concerning inclusive education. On the other hand, support from stakeholders related to the expectation built on 
the implementation of inclusive education is the phenomenon of legitimacy, the existence of which will explain the implementation of inclusive education in school. It is these phenomena that motivate the author to study specifically signification, resource domination and legitimacy of inclusive education thereby obtaining a description of inclusiveness achievement in school, in this case elementary school.

Inclusion is a new education service (new structure) in education implementation dynamic in Indonesia. The mainstreaming of inclusive school conducted continuously in the attempt of delivering information flow of inclusive school is the original form of communication in building interpretative framework of inclusive school among the community, particularly education community (school). Each component of education system (school) builds repeated interpretation about inclusive education in social activities conducted,thereby resulting in an interpretation on inclusive school. Such the process occurs and colors the relation reproduced between the actors (headmaster, teacher, students, supervisor, foundation administrator, and etc) as the actors or agents composed as the governing social practice.

The domination conducted by the leader (government, foundation administrator, headmaster) over teacher, students, parents and other resource existing in the school gives them authority in supporting and realizing the inclusive education. Furthermore, the interpretation occurring between teachers, students, parents and other components in school indicates the legitimacy given concerning inclusive education. Finally, legitimacy existing in social practice conducted by actor and the actor's ability in managing other resource will be created, in the form of normative rule or policy as the form of support and expectation to realize the inclusive school and to manage the learning process in school in order to achieve the intended objective of inclusive education.

\subsection{METHODOLOGY}

The research strategy of mix method used in this research was embedded concurrent strategy from Cresswell et al., (2003). This research specifically was conducted in 15 (fifteen) elementary schools organizing inclusive program in Surakarta City, Central Java, Indonesia. The number of research sample and the representation of public and private schools for the research sampling are shown in the table below:

Table 1: The Number of Research Sample

\begin{tabular}{|c|c|c|c|c|}
\hline \multirow{2}{*}{ No. } & \multirow{2}{*}{ School Name } & \multirow{2}{*}{ Sub District } & \multicolumn{2}{|c|}{ Teacher Number } \\
\hline & & & Regular $\left.^{*}\right)$ & $\left.\mathrm{GPK}^{* *}\right)$ \\
\hline 1 & $\begin{array}{l}\text { SD } \\
\text { NegeriBromantakan } \\
56\end{array}$ & \multirow{5}{*}{ Banjarsari } & 10 & 2 \\
\hline 2 & SD Al Firdaus & & 52 & 29 \\
\hline 3 & SD NegeriGebang & & 6 & 2 \\
\hline 4 & $\begin{array}{l}\text { SD Negeri } \\
\text { Manahan }\end{array}$ & & 7 & 0 \\
\hline 5 & SD LazuardiKamila & & 15 & 4 \\
\hline 6 & $\begin{array}{l}\text { SDN KarangAsem } \\
1\end{array}$ & \multirow{3}{*}{ Laweyan } & 6 & 2 \\
\hline 7 & SD Al Islam 1 & & 10 & 0 \\
\hline 8 & SD NegeriPajang 1 & & 10 & 3 \\
\hline 9 & SD Al Islam 2 & Serengan & 34 & 0 \\
\hline
\end{tabular}


Ravik Karsidi et. al. / UMRAN - International Journal of Islamic and Civilizational Studies. Vol.4, no.1-1, 01 - 07

\begin{tabular}{|c|c|c|c|c|}
\hline 10 & $\begin{array}{l}\text { SD } \\
\text { NegeriKartodipuran }\end{array}$ & & 7 & 2 \\
\hline 11 & SDN Carangan & \multirow{3}{*}{ PasarKliwon } & 9 & 2 \\
\hline 12 & SDN Wiropaten & & 6 & 2 \\
\hline 13 & SDN Harjodipuran & & 6 & 1 \\
\hline 14 & SDN Mojosongo 1 & \multirow{2}{*}{ Jebres } & 6 & 0 \\
\hline 15 & SD NegeriPetoran & & 10 & 3 \\
\hline \multicolumn{3}{|c|}{ Total Number of Teachers } & 197 & 49 \\
\hline \multicolumn{5}{|c|}{ Source: Secondary Data, 2015} \\
\hline \multicolumn{5}{|c|}{${ }^{*}$ Class Teacher or Subject Teacher } \\
\hline
\end{tabular}

The informants were selected purposively putting the headmaster and the coordinator of inclusion as the key informants considered as having adequate information, thereby the information selection can potentially develop corresponding to the author's need and determination to obtain data (Sutopo, 2002). In addition, informants were also selected using maximum variation sampling technique based on the variation of public and private schools organizing inclusive education program before and after the launching of Surakarta City as Inclusive City believing that there is a difference or diversity of education inclusivity. This strategy was intended not to generalize the findings of research, but to search for information that can explain the variation and meaningful general pattern in the variation (Slamet, 2006). Then, from every category, the purposive sampling technique was applied, and to get the next informant, snowball sampling technique was used. In this research, the measurement was conducted based on index for inclusion taking cultural and practical dimensions (Booth, 2002). Furthermore, the measurement of education inclusivity based on the two dimensions using indicators (1) the building of inclusive school community and inclusive values, and (2) the development of inclusive learning program.

\subsection{RESULT AND DISCUSSION}

\subsection{The Strong Relationship between Signification and Education Inclusivity}

The relationship between signification and education inclusivity is fairly strong and positive $(\mathrm{R}=$ $0.770)$. The contribution of signification to inclusiveness is $59.2 \%$ with $t_{\text {stat }}>t_{\text {table }}(18.827>1.960)$. It means that there was a positive effect of signification on education inclusiveness. This research showed that the signification on inclusive education plays an important role in the attempt of building and developing inclusive education environment,not only physically, but also the discussion in interpreting inclusion in daily life in school environment. Sociologically, this signification is important to consider in seeing the inclusion structuring occurring. The process of signifying inclusive education building positive mindset and attitude to inclusion continuously and repeatedly is very important to realize the inclusiveness of education in school.

\subsection{The Strong Relationship between Resource Domination and Education Inclusivity}

The relationship between domination and education inclusivity is fairly strong and positive $(\mathrm{R}=0.879)$. The contribution domination to inclusiveness is $77.3 \%$, with $t_{\text {stat }}>$ table $(28.866>1.960)$, meaning that there is a positive effect of resource domination on education inclusiveness. This research showed that the ability of activating, directing, planning, using, and allocating resource in implementing inclusive education is important to realize the inclusiveness of education in school. 


\subsection{The Strong Relationship between Legitimacy and Education Inclusivity}

The relationship between legitimacy and education inclusivity is fairly strong and positive ( $\mathrm{R}=0.816)$. The contribution of legitimacy to education inclusiveness is $66.6 \%$ with $t_{\text {stat }}>t_{\text {table }}(22.078>1.960)$, meaning that there is a positive effect of legitimacy on education inclusivity. The legitimacy on inclusive education in the form of support from all of school components and the development of guidelines, regulation, and school policy as the normative reference of inclusive implementation in school is very important in achieving the education inclusivity in school.

\subsection{The Strong Relationship of Signification, Domination and Legitimacy Simultaneously to Education Inclusivity}

The relationship of signification, domination and legitimacy simultaneously to education inclusivity is strong and positive $(\mathrm{R}=900)$. The contribution of those three predictor variables is $81 \%$ with $\mathrm{F}_{\text {statistic }}>\mathrm{F}_{\text {table }}(342.970>2.65)$, meaning that there is a positive effect of signification, domination and legitimacy simultaneously to education inclusiveness on education inclusiveness.

The form of signification on inclusive education is the availability ofspecial space for Children with Special Need, accessibility to school infrastructure, organizational structure including inclusion coordinator, mentioning inclusive education, inclusive education socialization, understanding and interpreting on inclusive education. The form of resource domination in education includes the availability of Special Counseling Teacher, the availability of identification and assessment, complete data of student history, participation in inclusion training, involvement of parents or other stakeholders, and individual learning program development, and the availability of operational budget for inclusion. The form of inclusive education legitimacy includes the availability of regulation as the foundation of inclusive education implementation, the presence of inclusive work program planning, the presence of inclusive supervision and monitoring from headmaster, the presence of inclusive building from headmaster, the components of school reminding and motivating eachothers in implementing inclusive education, the presence of initiative to give proposition for the progress of inclusion, and inclusive budget support from government and non-government. In addition to those forms above, there are work culture and religious values affecting the variation of education inclusivity between public and private schools.

\subsection{CONCLUSION}

The conclusion is that signification, resource domination of inclusion and legitimacy of inclusive education have a significant contribution in the realization of education inclusivity. The results show that inclusivity of education in fifteen elementary schools in Surakarta are still have low condition of signification, resource domination and legitimacy of inclusive education. All three are linked and have important part in realizing inclusivity of education as a structure that can be implemented and supported by all stakeholders.

\section{REFERENCES}

Booth, Tony \& Ainscow, Mel.(2002). Index for Inclusion. Center for Studies on Inclusive Education.

Cresswell, John W. (2012). Research Design Pendekatan Kualitatif, Kuantitatif dan Mixed. Yogyakarta: Pustaka Pelajar.

Giddens, Anthony. (2010). Teori Strukturasi Dasar-dasar Pembentukan Struktur Sosial Masyarakat. Yogyakarta: Pustaka Pelajar.

Karsidi, Ravik. (2008). Sosiologi Pendidikan. Surakarta: UNS Press.

Permendiknas Nomor 70 Tahun 2009 tentang PendidikanInklusif (Pensif) Bagi PesertaDidik yang Memiliki Kelainan dan Memiliki Potensi Kecerdasan dan/atau Bakat Istimewa. 
Ravik Karsidi et. al. / UMRAN - International Journal of Islamic and Civilizational Studies. Vol.4, no.1-1, 01 - 07

Pernyataan Salamanca dan Kerangka Aksi Pendidikan Kebutuhan Khusus, (1994).

Sutopo, H.B. (2002). Metodologi Penelitian Kualitatif. UNS Press: Surakarta.

Slamet, Y. (2006). Metode Penelitian Sosial. Surakarta: LPP UNS dan UNS Press.

Undang-Undang Republik Indonesia Nomor 20 Tahun 2003 tentang Sistem Pendidikan Nasional.

Yusuf, Munawir. (2014). Model ManajemenPendidikanInklusif. Disertasi, Universitas Negeri Semarang. 